sitions and stochastic models are expertly and critically assessed in the roles which they are playing in advancing this blossoming field. In all, a unique collection of theoretical articles.

\section{School of Chemistry}

University of Leeds

Leeds LS2 9JT

England

Acta Cryst. (1979). A35, 1090

\section{Books Received}

The following books have been received by the Editor. Brief and generally uncritical notices are given of works of marginal crystallographic interest; occasionally a book of fundamental interest is included under this heading because of difficulty in finding a suitable reviewer without great delay.

Scientific information transfer: the editor's role. Edited by Miriam Balaban. Pp. xxxii + 686. Dordrecht: Reidel, 1978. Price Dfl 70.00, US $\$ 34.50$. A review of this book, by A. J. C. Wilson, has been published in the September issue of Acta Crystallographica, Section B, pages 2285-2286.
Space groups for solid state scientists. By G. BURNS and A. M. Glazer. Pp. xii + 278. New York, San Francisco, London: Academic Press, 1978. Price £9.40, US \$14.50. A review of this book, by H.-U. Schuster, has been published in the August issue of Journal of Applied Crystallography, page 428 .

Landolt-Börnstein. Numerical data and functional relationships in science and technology. Group III. Crystal and solid state physics. Vol. 11. Elastic, piezoelectric, pyroelectric, piezooptic, electrooptic constants and nonlinear dielectric susceptibilities of crystals. (Revised and extended edition of Vols III/1 and III/2.) By M. M. CHOY, W. R. CoOK, R. F. S. Hearmon, H. JafFe, J. Jerphagnon, S. K. Kurtz, S. T. LiU and D. F. Nelson. Pp. xvi +854 . Berlin: Springer, 1979. Price (cloth) DM 780.000, US \$429.00.

Landolt-Börnstein. Numerical data and functional relationships in science and technology. Group III. Crystal and solid state physics. Vol. 7. Crystal structure data of inorganic compounds. Part c2. By W. PIEs and A. WeIss. Key elements: P, As, Sb, Bi. Substances Nos. c1134 to c3338. Pp. xxvii + 452. Berlin: Springer, 1979. Price (cloth) DM 550, ca US \$302. 